\title{
Isolation and Molecular Identification of Keratinase- Producing Bacteria from the Sludge of Qeshm Island
}

\author{
Maedeh Kiani Abri (MSc) \\ Department of Microbiology, Islamic \\ Azad University, Falavarjan Branch, \\ Isfahan, Iran \\ Monir Doudi (PhD) \\ Department of Microbiology, Islamic \\ Azad University, Falavarjan Branch, \\ Isfahan, Iran \\ Ali Mohammad Ahadi (PhD) \\ Department of Genetics, Shahrekord \\ University, Shahrekord, Iran \\ Tel: +983137420134 \\ Email: Monirdoudi@yahoo.com \\ Corresponding author: Monir Doudi \\ Address: Islamic Azad University, \\ Falavarjan Branch, Isfahan, Iran \\ Received : 01 Nov 2017 \\ Revised: 02 Dec 2017 \\ Accepted: 16 Dec 2017 \\ Maedeh Kiani Abri307934992
}

\section{ABSTRACT}

Background and 0bjectives: Keratinase is an enzyme commonly used in the production of detergents, cosmetics, drugs, leather, and other industries. Considering the high cost of traditional methods for decomposition of feather, hair, hooves, nails, and wool that contain high levels of keratin, their biodegradation with keratinase-producing bacteria can be a valuable solution. The present study aimed for isolation and molecular identification of keratinase-producing bacteria in Qeshm Island and Peyposht village in Iran.

Methods: Water and sludge samples from the Qeshm Island and Peyposht village were collected. The bacteria isolates were screened for keratinase production using the Lowry method. Effect of $\mathrm{pH}$ and temperature was assessed on the production of keratinase and on the growth of the isolates. Colony-polymerase chain reaction was used for molecular identification of the isolates.

Results: Bacillus berevis and Enterobacter cloacae were isolated in this study. Keratinase production in B. berevis was highest at pH 7.5 and $35^{\circ} \mathrm{C}$. In addition, the highest level of enzyme production by E. cloacae was observed at $\mathrm{pH} 7$ and $37^{\circ} \mathrm{C}$.

Conclusion: It seems that the bacterial strains isolated from sludge in the study area have relatively favorable keratinase production capacity.

Keywords: Bacteria, Colony PCR, Identification, Keratinolytic protein, Sewage.

This paper should be cited as: Kiani Abri M, Doudi M, Ahadi AM[Isolation and Molecular Identification of Keratinase-Producing Bacteria from the Sludge of Qeshm Island]. mljgoums. 2018; 12(3):34-40 


\section{INTRODUCTION}

Keratinase is an extracellular protease that decomposes scleroprotein, keratin. Microbial keratinases are alkaline or neutral proteases that functions best in $\mathrm{pH}$ of 7.5-9 and at $40-85{ }^{\circ} \mathrm{C}$ (1). The most important producers of keratinase include fungi (Microsporum, Trichophyton, Aspergillus flavus and Aspergillus fumigatus), bacteria (Bacillus pumilus, Bacillus cereus, Bacillus licheniformis and Bacillus subtilis), and Actinomycetes (Streptomyces albidoflavus and Streptomyces pactum) (2-5) that are capable of hydrolyzing insoluble keratin. Most keratinolytic strains are able to decompose feather keratin within $48 \mathrm{~h}$ of keratinase production, indicating the potential applicability of the enzyme for bioconversion of keratin wastes into valuable products (6). Keratinous waste is widely generated by various industries. Feathers are byproducts of poultry production that can provide suitable conditions for the growth of anaerobic or aerobic bacteria if not removed from the environment $(7,8)$. Thus, it is necessary to investigate the production of keratinase with particular emephisis on enzyme extraction technology at industrial scale. We aimed to study the isolation and molecular identification of keratinase-producing bacteria in Qeshm Island and Peyposht village in Iran.

\section{MATERIAL AND METHODS}

Water and sludge samples collected from separate beaches of Peyposht and Qeshm were transferred to the laboratory of Islamic Azad University of Falavarjan, Iran. Biologocal oxygen demand (BOD) and chemical oxygen demand (COD) were measured as indicators of water quality.

In order to prepare feather powder, raw chicken feathers were cut into small pieces (1$3 \mathrm{~cm}$ ) and then rinsed with water several times. Next, $500 \mathrm{~g}$ of the pieces were placed in $1 \mathrm{~L}$ of 1:1 chloroform-methanol mixture (v/v) for two days. The pieces were then placed in a 4:3:1 chloroform-acetone-methanol mixture (v/v) for two days for degreasing. In order to remove residual solvents, the small feather pieces were washed with distilled water several times, rinsed and dried for three days at $60{ }^{\circ} \mathrm{C}$. Finally, the pieces were powdered using a home mill and then kept in a capped sterile bottle until use (2).
In order to isolate keratinase-producing bacteria, $10 \mathrm{ml}$ of the samples along with 2 to 3 chicken feathers were added to $90 \mathrm{ml}$ of distilled water and then stored at $30{ }^{\circ} \mathrm{C}$ in a shaking incubator (at $180 \mathrm{rpm}$ ) for 24 hours. Serial dilutions $\left(10^{-1}-10^{-6}\right)$ were prepared from the samples. Then, $100 \mathrm{ml}$ of each dilution was added to FMB medium containing $0.1 \mathrm{~g} / \mathrm{L}$ yeast extract, $0.5 \mathrm{~g} / \mathrm{L} \mathrm{NaCl}, 0.5 \mathrm{~g} / \mathrm{L} \mathrm{NH}_{4} \mathrm{Cl}, 0.3$ $\mathrm{g} / \mathrm{L} \mathrm{K}_{2} \mathrm{HPO}_{4}, 0.4 \mathrm{~g} / \mathrm{L} \mathrm{KH}_{2} \mathrm{PO}_{4}, 0.1 \mathrm{~g} / \mathrm{L} \mathrm{MgSO}$, $10 \mathrm{~g} / \mathrm{L}$ feather powder, and $0.0001 \mathrm{~g} / \mathrm{L}$ cyclohexamide. Bacterial growth was assessed after transferring $1 \mathrm{ml}$ of sample-FMB mixture was to FMA (solid feather culture medium with $2 \%$ agar). In order to obtain colonies, the bacteria were first cultured on nutrient agar by streaking and then incubated at $37{ }^{\circ} \mathrm{C}$ for $24 \mathrm{~h}$ $(9,10)$. After characterization with Gram staining and morphology, the colonies were transferred and incubated in skim milk agar to separate hemolytic bacteria (11). Keratinaseproducing isolates were cultured in liquid FMB medium containing $100 \mathrm{~g}$ of powdered feathers for $72 \mathrm{~h}$. After filtration through a Whatman paper, the medium containing the enzyme was centrifuged at $3500 \mathrm{rpm}$ for 30min. Next, $1 \mathrm{ml}$ of supernatant was mixed with $1 \mathrm{ml}$ of $50 \mathrm{mM}$ Tris-HCl buffer (Merck, Germany) at $\mathrm{pH} 8$ and $1 \mathrm{ml}$ of $0.5 \%$ soluble keratin (Sigma, USA). After heating at $50{ }^{\circ} \mathrm{C}$ for $10 \mathrm{~min}$ and then adding $2 \mathrm{ml}$ of $0.4 \mathrm{M}$ $\mathrm{CH}_{3} \mathrm{Cl}_{3}$ (Sigma, USA), the mixture was centrifuged at $3500 \mathrm{rpm}$ and for $10 \mathrm{~min}$ at $4^{\circ} \mathrm{C}$. Optical density (OD) of the solution was read at $280 \mathrm{~nm}$ against a control prepared by mixing $2 \mathrm{ml}$ of $0.4 \mathrm{M}$ TCA with $1 \mathrm{ml}$ of enzyme extract (0.01U) (12). Lowry protein assessment kit was used to measure total protein, and standard curve was plotted using different concentrations of BSA. To determine the optimal $\mathrm{pH}$ for the growth of bacteria, FMB medium was prepared at different $\mathrm{pH}$ values $(6.4,6.8,7,7.2$ and 7.5). A colony of bacteria was added to shake flasks (at 180 $\mathrm{rpm}$ ), which were later incubated at $30^{\mathrm{c}} \mathrm{o}$. Serial dilutions $\left(10^{-1}-10^{-6}\right)$ were prepared in six tubes containing $9 \mathrm{ml}$ of sterile distilled water. After $24 \mathrm{~h}$ of incubation at $30{ }^{\circ} \mathrm{C}$, the number of colonies was counted. To determine the optimal growth temperature, a bacterial colony was inoculated in FMB medium ( $\mathrm{pH}$ 7.5). The flasks were placed in a shaking incubator at $180 \mathrm{rpm}$ for three days at various temperatures 
$\left(28,30,32,34\right.$ and $\left.36{ }^{\circ} \mathrm{C}\right)$ for $12,24,48,72$ and 96 hours. In order to isolate keratinaseproducing bacteria, $10 \mathrm{ml}$ of the samples along with 2 to 3 chicken feathers were added to $90 \mathrm{ml}$ of distilled water and then stored at $30^{\circ} \mathrm{C}$ in a shaking incubator (at $180 \mathrm{rpm}$ ) for 24 hours. Serial dilutions $\left(10^{-1}-10^{-6}\right)$ were prepared from the samples. Then, $100 \mathrm{ml}$ of each dilution was added to FMB medium containing $0.1 \mathrm{~g} / \mathrm{L}$ yeast extract, $0.5 \mathrm{~g} / \mathrm{L} \mathrm{NaCl}$, $0.5 \mathrm{~g} / \mathrm{L} \quad \mathrm{NH}_{4} \mathrm{Cl}, 0.3 \mathrm{~g} / \mathrm{L} \quad \mathrm{K}_{2} \mathrm{HPO}_{4}, 0.4 \mathrm{~g} / \mathrm{L}$ $\mathrm{KH}_{2} \mathrm{PO}_{4}, \quad 0.1 \mathrm{~g} / \mathrm{L} \quad \mathrm{MgSO}_{4}, \quad 10 \mathrm{~g} / \mathrm{L}$ feather powder, and $0.0001 \mathrm{~g} / \mathrm{L}$ cyclohexamide. Bacterial growth was assessed after transferring $1 \mathrm{ml}$ of sample-FMB mixture was to FMA (solid feather culture medium with $2 \%$ agar).

In order to obtain colonies, the bacteria were first cultured on nutrient agar by streaking and then incubated at $37{ }^{\circ} \mathrm{C}$ for $24 \mathrm{~h}(9,10)$. After characterization with Gram staining and morphology, the colonies were transferred and incubated in skim milk agar to separate hemolytic bacteria (11).

Keratinase-producing isolates were cultured in liquid FMB medium containing $100 \mathrm{~g}$ of powdered feathers for $72 \mathrm{~h}$. After filtration through a Whatman paper, the medium containing the enzyme was centrifuged at 3500 rpm for 30min. Next, $1 \mathrm{ml}$ of supernatant was mixed with $1 \mathrm{ml}$ of $50 \mathrm{mM}$ Tris- $\mathrm{HCl}$ buffer (Merck, Germany) at pH 8 and $1 \mathrm{ml}$ of $0.5 \%$ soluble keratin (Sigma, USA). After heating at $50{ }^{\circ} \mathrm{C}$ for $10 \mathrm{~min}$ and then adding $2 \mathrm{ml}$ of $0.4 \mathrm{M} \mathrm{CH}_{3} \mathrm{Cl}_{3}$ (Sigma, USA), the mixture was centrifuged at $3500 \mathrm{rpm}$ and for $10 \mathrm{~min}$ at $4{ }^{\circ} \mathrm{C}$. Optical density (OD) of the solution was read at $280 \mathrm{~nm}$ against a control prepared by mixing $2 \mathrm{ml}$ of $0.4 \mathrm{M}$ TCA with $1 \mathrm{ml}$ of enzyme extract (0.01U) (12).

Lowry protein assessment kit was used to measure total protein, and standard curve was plotted using different concentrations of BSA.

To determine the optimal $\mathrm{pH}$ for the growth of bacteria, FMB medium was prepared at different $\mathrm{pH}$ values $(6.4,6.8,7,7.2$ and 7.5). A colony of bacteria was added to shake flasks (at $180 \mathrm{rpm}$ ), which were later incubated at $30^{\mathrm{c}} \mathrm{o}$. Serial dilutions $\left(10^{-1}-10^{-6}\right)$ were prepared in six tubes containing $9 \mathrm{ml}$ of sterile distilled water. After $24 \mathrm{~h}$ of incubation at $30{ }^{\circ} \mathrm{C}$, the number of colonies was counted.

To determine the optimal growth temperature, a bacterial colony was inoculated in FMB medium ( $\mathrm{pH}$ 7.5). The flasks were placed in a shaking incubator at $180 \mathrm{rpm}$ for three days at various temperatures $(28,30,32,34$ and 36 ${ }^{\circ} \mathrm{C}$ ) for $12,24,48,72$ and 96 hours. FMB liquid medium with a $\mathrm{pH}$ range of 5-9 was prepared by addition of $\mathrm{HCl}$ or $\mathrm{NaOH}$. After inoculation of bacteria into the culture medium with different $\mathrm{pH}$ values, each tube was placed in a shaking incubator for $72 \mathrm{~h}$ at $37{ }^{\circ} \mathrm{C}$. A sample was taken from each tube for analysis of keratinase production at different temperatures $\left(20,25,30,37,40\right.$ and $\left.45^{\circ} \mathrm{C}\right)$ (12).

For molecular identification of keratinaseproducing bacteria, polymerase chain reaction was performed universal primers with the following sequences: (forward) 5'AGGAGGTGATCCAACGCA3' and (reverse)

5'AACTGGAGGAAGGTGGGGAT3' for gram positive bacteria and (forward) 5'CCATTGTAGCACGTGTGT3' and (reverse) 5'CCATTGTAGCACGTGTGT3' for gram negatives bacteria (13). Cycling conditions were as follows: initial denaturation at $95{ }^{\circ} \mathrm{C}$ for $5 \mathrm{~min}$, denaturation at $94{ }^{\circ} \mathrm{C}$ for 30 $\mathrm{sec}$, annealing at $50{ }^{\circ} \mathrm{C}$ for $30 \mathrm{sec}$, extension at $72{ }^{\circ} \mathrm{C}$ for $70 \mathrm{sec}$, and final extension at $72{ }^{\circ} \mathrm{C}$ for $5 \mathrm{~min}$. After performing colony PCR and gel electrophoresis, the results were interpreted and evaluated on the NCBI database.

\section{RESULTS}

As shown in table 1, $\mathrm{pH}$ of both samples was in the acidic range with a minor difference. BOD of the sample collected from Peyposht was higher than that of the Qeshm Island.

Table 1-Biological properties of the sludge samples collected from beaches in Qeshm

\begin{tabular}{ccccc}
\hline Sampling site & Temperature $\left({ }^{\circ} \mathrm{C}\right)$ & pH & BOD $(\mathrm{mg} / \mathrm{L})$ & COD $(\mathrm{mg} / \mathrm{L})$ \\
\hline Qeshm & 33 & 5 & 760 & 1510 \\
Peyposht & 31 & 6 & 930 & 1434 \\
\hline
\end{tabular}


PCR products were identified using a $50 \mathrm{bp}$ DNA ladder and then were sent for sequencing. The samples from Qeshm had 99\% similarity with $16 \mathrm{~S}$ rRNA of $B$. berevis, while the sequence of samples from Peyposht had $96.5 \%$ similarity with E. cloacae. The optimal $\mathrm{pH}$ for the growth of $B$. berevis and E.cloacae was 7.2 and 7.5 , respectively. These bacteria were also able to grow at 28 , $30,32,34$ and $36^{\circ} \mathrm{C}$. Nevertheless, the optimal temperature for the growth of $B$. berevis and $E$. cloacae in FMB was $32{ }^{\circ} \mathrm{C}$ and $34{ }^{\circ} \mathrm{C}$, respectively.

Keratinase production by the two bacteria was measured in the FMB medium with different $\mathrm{pH}$ values. Maximum keratinase production (71.24 U/mL) by B. berevis was observed in $\mathrm{pH} 7.5$ (Figure 5). In addition, maximum keratinase production $(52.29 \mathrm{U} / \mathrm{mL})$ by $E$. cloacae was observed in $\mathrm{pH} 7$ (Figure 6).

Figure 1- Growth of $B$. berevis in different $\mathrm{pH}$ ranges

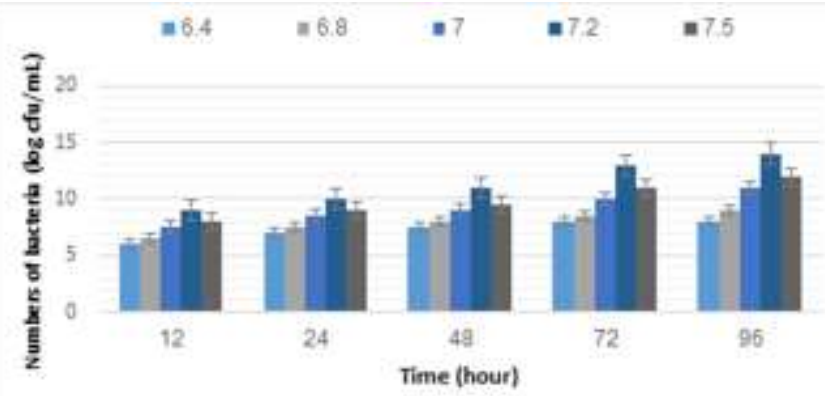

Figure 2- Growth of $E$. cloacae in different $\mathrm{pH}$ ranges

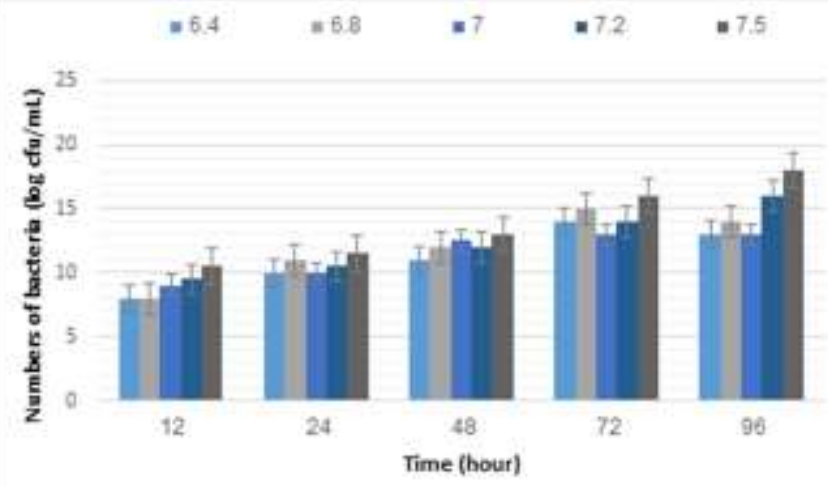

Figure 3- Growth of $\boldsymbol{B}$. berevis at different temperatures

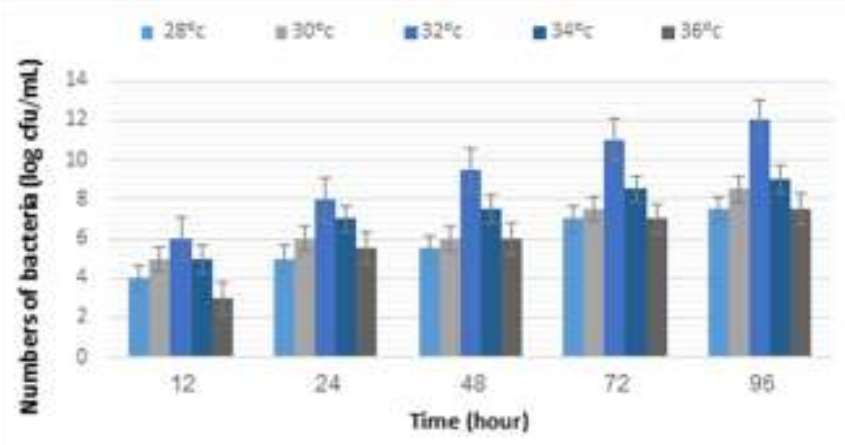

Figure 4- Growth of E. cloacae at different temperatures

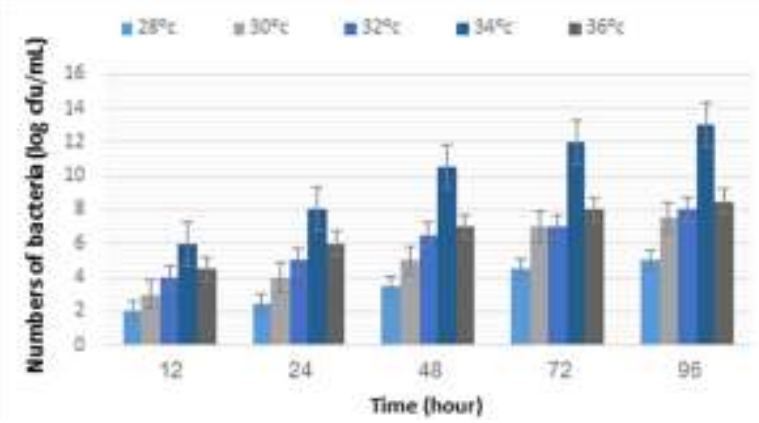


Keratinase production by the two bacteria was measured in the FMB medium with different $\mathrm{pH}$ values. Maximum keratinase production (71.24 U/mL) by B. berevis was observed in pH 7.5 (Figure 5).

In addition, maximum keratinase production $(52.29 \mathrm{U} / \mathrm{mL})$ by $E$. cloacae was observed in pH 7 (Figure 6). We also measured keratinase production by the two bacteria in different temperatures. Maximum keratinase production $(59.4 \mathrm{U} / \mathrm{mL})$ by $B$. berevis was noted at $35^{\circ} \mathrm{C}$, while minimum enzyme production (14.07 $\mathrm{U} / \mathrm{mL}$ ) was observed at $20{ }^{\circ} \mathrm{C}$ (Figure 7). Moreover, maximum enzyme production $(68.88 \mathrm{U} / \mathrm{mL})$ by E. cloacae was recorded at $37{ }^{\circ} \mathrm{C}$, while minimum enzyme production $(25.29 \mathrm{U} / \mathrm{mL})$ was observed at $20{ }^{\circ} \mathrm{C}$ (Figure 8).

Figure 5- Keratinase production by $B$. berevis after 72 hours of incubation at $37^{\circ} \mathrm{C}$ in different $\mathrm{pH}$ values

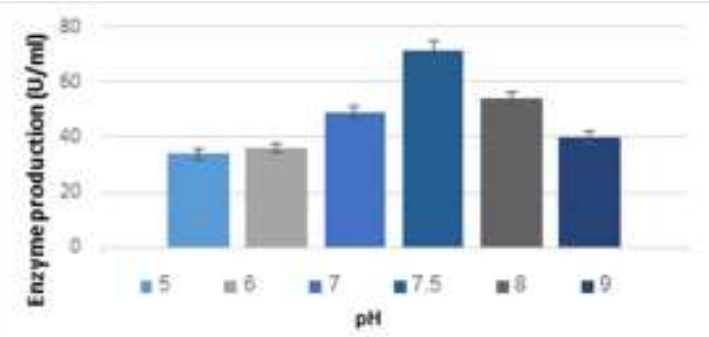

Figure 6- Keratinase production by $E$. cloacae after 72 hours of incubation at $37^{\circ} \mathrm{C}$ in different $\mathrm{pH}$ values

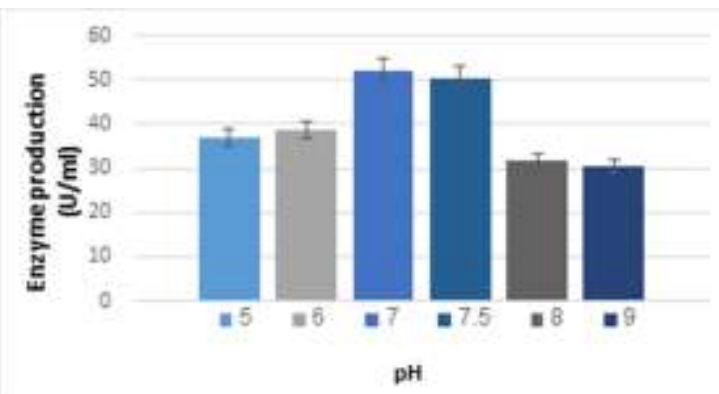

Figure 7- Keratinase production by $\boldsymbol{B}$. berevis at different temperatures (after 72 hours)

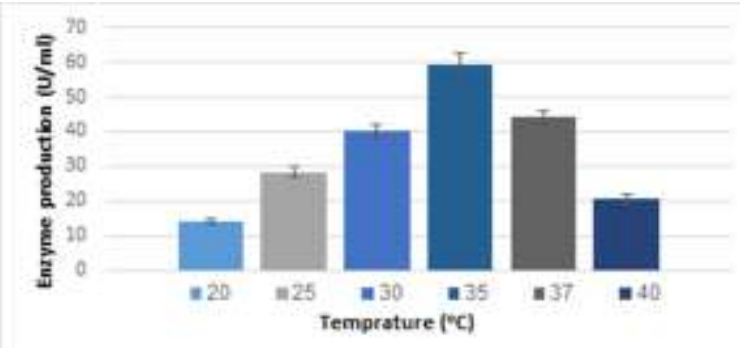

Figure 8- Keratinase production by $\boldsymbol{E}$. cloacae at different temperatures (after 72 hour)

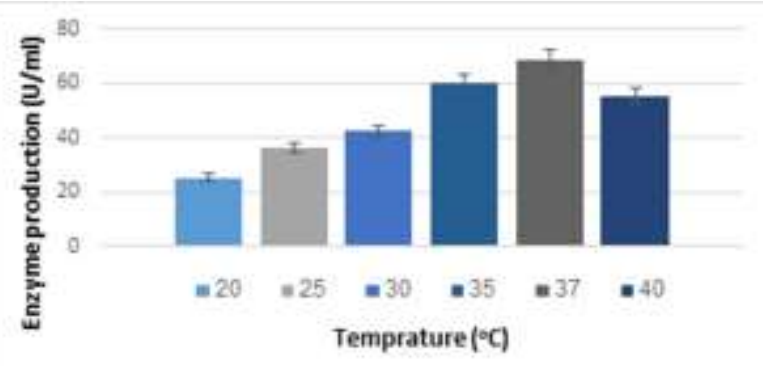


The protein content of $B$. berevis and $E$. cloacae at $650 \mathrm{~nm}$ was $0.649 \mathrm{mg} / \mathrm{mL}$ and $0.669 \mathrm{mg} / \mathrm{mL}$, respectively.

\section{DISCUSSION}

Today, environmental water pollution and the increasing amount of industrial wastewater poured into waters require proper management. Due to its insoluble nature, keratin is usually resistant to degradation by proteolytic enzymes such as pepsin, trypsin and papain. Keratin-degrading microorganisms can grow in various environments such as soil, air, forage, and waste (14). In this study, we aimed at isolation and molecular identification of bacterial strains from sludge samples collected from Peyposht and Qeshm, which have high quantities of keratin-rich waste.

In a study by Tork et al., 7 of 23 bacterial isolates with bright halos on skim milk agar were identified as keratinase producer (15). A study by Sangali and Brandli reported the keratinolytic activity of Vibrio sp. strain KR2 in a medium containing raw feather (16). In 2007, Joshi et al. isolated 3 keratinolytic Bacillus sp. from the Amazon River, which had $90 \%$ similarity with the 16S rRNA sequence of B. subtilis, B. amyloliquefaciens, and $B$. velezensis (17). On the contrary, some studies relied on the biochemical detection and isolation of keratinolytic bacteria. For instance, Pandian et al. found colonies with high keratinase production by using the Bergey's Manual (18). However, we identified the isolates by microscopic and macroscopic examinations and based on the 16S rRNA sequence of the isolates. The results showed that the isolates from the Qeshm beach are most likely $(96.5 \%)$ B. berevis, while the isolates from the Peyposht village are likely to be $(99 \%)$ E. cloacae. We also determined the optimal $\mathrm{pH}$ and temperature for the growth of these isolates. In study of Sangali and Brandeli, the optimal growth of keratinolytic Vibrio sp. strain $K R 2$ was observed at $\mathrm{pH}=7$ and $30{ }^{\circ} \mathrm{C}(16)$.

The isolated bacteria could grow at 28, 30, 32, 34 and $36^{\circ} \mathrm{C}$ but the optimal growth temperature after 96 hours for Bacillus and Enterobacter was $32{ }^{\circ} \mathrm{C}$ and $34^{\circ} \mathrm{C}$, respectively.

In this study, the amount of BOD and COD of sludge of water taken from the Qeshm beach and Peyposht village was notably higher than the standard value, indicating the high and hazardous level of contamination in these areas. Higher COD values compared to $\mathrm{BOD}_{5}$ is observed when toxic compounds are present in the wastewater, which inhibits the activity of organisms that degrade organic materials.

In this study, we examined the effect of $\mathrm{pH}$ on keratinase production by $B$. berevis and $E$. cloacae. The results showed that maximum keratinases production by $B$. berevis $(71.24$ $\mathrm{U} / \mathrm{ml})$ and E. cloacae $(52.29 \mathrm{U} / \mathrm{ml})$ is at $\mathrm{pH} 7.5$ and 7 , respectively. Nadia et al. reported that the optimal $\mathrm{pH}$ for keratinase production in $B$. berevis is 7.5, 8 and 9 (19). Kim et al. also claimed that keratinase production in $B$. cereus, $B$. subtilis and in $B$. pumilus is highest

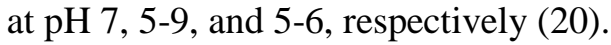

The highest and lowest level of keratinase production in B. berevis was observed at $35^{\circ} \mathrm{C}$ and $20{ }^{\circ} \mathrm{C}$, respectively. However, Nadia et al. reported $40{ }^{\circ} \mathrm{C}$ as the optimal temperature for keratinase production (19). This difference can be related to physicochemical conditions of the two studies and the genus of bacteria examined.

In 2009, Xu et al. measured the amount of soluble proteins produced by $B$. licheniformis $K-19$ using folin phenol and bovine serum albumin. After 36 hours of incubation at $37^{\circ} \mathrm{C}$, the concentration of soluble protein was almost $3 \mathrm{mg} / \mathrm{ml}$ (21).

Matikeviciene et al. studied the level of keratinase production in some Bacillus species at $565 \mathrm{~nm}$ and using the Lowry method. According to their findings, $B$. subtilis, $B$. licheniformis, B. subtilis, and B. pumilus produced $1.23,1.17,1.16$, and $1.05 \mathrm{mg} / \mathrm{ml}$ keratinase, respectively (22). However, in the present study, the amount of enzyme produced by $B$. berevis and E. cloacae was $0.649 \mathrm{mg} / \mathrm{ml}$ at $650 \mathrm{~nm}$, respectively. This inconsistency could be attributed to the difference in bacterial species and the wavelength used for measurement of keratinase production.

\section{CONCLUSION}

Keratin waste is a favorable environment for the growth of keratinaseproducing bacteria. Most of these bacteria are of Bacillus genus since they can produce spore and survive adverse environmental conditions. The optimal $\mathrm{pH}$ for the growth of keratinase-producing bacteria is in the neutral to acidic range, while the optimal $\mathrm{pH}$ range for keratinase production 
is in the neutral to alkaline range. In addition, the optimal temperature for the growth of bacteria and keratinase production is $32-34{ }^{\circ} \mathrm{C}$ and $35-37^{\circ} \mathrm{C}$, respectively.

The bacteria isolates in our study were gramnegative spore-forming Bacillus sp. with high enzyme production.

\section{REFERENCES}

1. Agrahari S, Wadhwa N. Degradation of chicken feather a poultry wasteproductby keratinolytic bacteria isolated from dumping site at ghazipurpoultry processing plant. International Journal of Poultry Science. 2010; 9(5): 482-489. DOI: 10.3923/ijps.2010.482.489.

2. Agrahar S. Production of extracellular Keratinase Enzymes from Bacillus pumilis SN3 isolated from soil sample of ghazipur poultry waste site. International Journal of Sustainable Development and Green Economics. 2013; 2(1):109-113.

3. Allpress JD, Mountain G, Gowland PC. Production, purification and characterization of an extracellular keratinase from Lysobacter NCIMB 9497. Letters in Applied Microbiology. 2012; 34(5): 337-342.

4. Belarmino DD, Ladchumananandasivam R, Belarmino LD, Pimentel JRDM, Brismark G, Da Rocha BGD, et al. Physicaland Morphological Structure of Chicken Feathers (Keratin Biofiber) in Natural. Chemically and Thermally Modified Forms Materials Sciences and Applications. 2012; 3(12): 887-893. DOI: 10.4236/msa.2012.312129.

5. Bin W, Wen Y, Joanna MC, Mark AM. Keratin: structure, mechanical properties, occurrence in biological organisms and efforts at bioinspiration. ELSEVIER. 2016; 76: 229-318.

6. Bockle B, Galunsk B, Mulle R. Characterization of a keratinolytic serineprotease from Streptomyces pactum DSM40530. Applied and Environmental Microbiology. 1995; 61: 3705-3710.

7. Brandelli A. Hydrolysis of native proteins by a keratinolytic strain of Chryseobacterium $s p$. Annals of Microbiology. 2005; 55(1): 47-50.

8. Brandelli A, Riffel A. Production of an extracellular keratinase from Chryseobacterium sp. growing on raw feathers. Electronic Journal Biotechnology. 2005; 8(1): 35-42.

9. Brandelli A. Bacterial Keratinases: Useful Enzymes for Bioprocessing Agroindustrial Wastes and Beyond Food Bioprocessing Technology. 2013; 1(2): 105-116.

10. Bressolier P, Letourneau F, Urdaci M, Verneuil B. Purification and characterization of a keratinolytic serine proteinase from Streptomyces albidoflavus. Applied and Environmental Microbiology. 1999; 65: 2570-2576.

11. Cai CG, Chen JS, Qi JJ, Yin Y, Xiao-dong Zheng XD. Purification and characterization of keratinase from a new Bacillus subtilis strain. Journal of Zhejiang University Science. 2008; 9(9): 713-720. doi: 10.1631/jzus.B0820128.

\section{ACKNOWLEDGEMENTS}

Many thanks to the respectable authorities of Islamic Azad University of Falavarjan and staff of the Research Laboratory.

\section{CONFLICT OF INTEREST}

None declared.

12. CAI CG, Lou BG, Zheng XD. Keratinase production and keratin degradation by a mutant strain of Bacillus subtilis. Journal of Zhejian University Science. 2008; 1(1): 60-67. doi: 10.1631/jzus.B061620.

13. Chu WH. Optimization of extracellular alkaline protease production from species of Bacillus. Journal of Indian Microbiology Biotechnology. 2007; 34(3): 241245 .

14. Gupta S, Singh R. Statistical modeling and optimization of keratinase production from newly isolated Bacillus subtilis RSE163. International Journal of Advanced Biotechnology and Research. 2013; 4(1): 167-174.

15. Tork S, Aly MM. Nawar L. Biochemical and molecular characterization of a new local keratinase producing Pseudomomanas sp.MS21. Asian Journal of Biotechnology. 2013; 2(1): 1-13.

16. Sangali S, Brandelli A. Feather keratin hydrolysis by a Vibrio sp. strain KR-2. Journal of Applied Microbiology. 2000; 89(5): 735-743.

17. Joshi SG, Tejashwini MM, Revati N, Sridevi R, Roma D. Isolation, Identification and Characterization of a Feather Degrading Bacterium. International Journal of Poultry Science. 2007; 6(9): 689-693.

18. Pandian S, Sundaram J, Panchatcharam P. Isolation, identification and characterization of feather degrading bacteria. European Journal of Experimental Biology. 2012; 2(1): 274-282.

19. Nadia ZJ, Hatem R, Abdelmalek B, Sahar T, Mouna $\mathrm{B}$, Amina BY, et al. Biochemical and molecular characterization of a serin keratinase from Brevibacillus brevis US575 with promising keratin-biodegradation and hide-dehairing activities. PLOS ONE. 2013; 8(10): e76722.

20. Kim JM, Lim WJ, Suh HJ. Feather-degrading Bacillus species from poultry waste. Process Biochemistry. 2001; 37(3): 287-291.

21. Xu B, Zhong Q, Tang X, Yang Y, Huang Z. Isolation and characterization of a new keratinolytic bacterium that exhibits significant feather-degrading capability. African Journal of Biotechnology, 2009; 8(18): 1-13.

22. Matikeviciene V, Masiliuniene D, Grigiskis S. Degradation of keratin containing wastes by bacteria with keratinolytic activity. Environmental Technology Resources. 2009; 1: 284-289. DOI: 10.17770/etr2009vol1.1107. 